
\title{
25 Research Soure \\ Quantitative Spectrofluorometric Assay Detecting Nuclear Condensation and Fragmentation in Intact Cells
}

\author{
Pavlina Majtnerova \\ University of Pardubice \\ Jan Capek \\ University of Pardubice \\ Filip Petira \\ University of Pardubice \\ Jiri Handl \\ University of Pardubice \\ Tomáš Roušar ( $\nabla$ tomas.rousar@upce.cz ) \\ University of Pardubice
}

\section{Research Article}

Keywords: nuclear condensation, nuclear fragmentation, spectrofluorometric assay, Hoechst probes, cell death, apoptosis

Posted Date: February 17th, 2021

DOI: https://doi.org/10.21203/rs.3.rs-208670/v1

License: (1) This work is licensed under a Creative Commons Attribution 4.0 International License. Read Full License 


\section{Abstract}

At present, nuclear condensation and fragmentation have been estimated also using Hoechst probes in fluorescence microscopy and flow cytometry. However, none of the methods has used the Hoechst probes for quantitative spectrofluorometric assessment. Therefore, the aim of present study was to develop a spectrofluorometric assay for detection of nuclear condensation and fragmentation in intact cells. We used HepG2 and HK-2 cells cultured in 96-well plates which were treated with potent apoptotic inducers (i.e. cisplatin, staurosporine, camptothecin) for 6-48 h. Then, the cells were incubated with Hoechst 33258 $(2 \mu \mathrm{g} / \mathrm{mL})$ and the increase of fluorescence after binding of the dye to DNA was measured. The developed spectrofluorometric assay was capable to detect nuclear changes caused by all tested apoptotic inducers. Then, we compared the outcomes of the spectrofluorometric assay with other methods detecting apoptosis (i.e. TUNEL, DNA ladder, caspase activity). We found that the developed assay provides results of same sensitivity as TUNEL assay but the advantages of the spectrofluorometric assay are fast processing, low-cost and high throughput. Because nuclear condensation and fragmentation can be typical markers of cell death, especially in apoptosis, we suppose that the spectrofluorometric assay could become a routinely used method for characterizing cell death processes.

\section{Introduction}

Apoptosis is a complex process including various morphological and biochemical cellular changes that can be used to apoptosis characterization. The morphological changes include shrinkage of the cell, pyknosis and karyorrhexis followed by DNA fragmentation in late stage of apoptosis ${ }^{1,2}$. Then, the cellular cytoskeleton is damaged leading to membrane blebbing and, finally, apoptotic bodies formation ${ }^{1-3}$.

Nuclear condensation and fragmentation have been used as markers for late stages of apoptosis ${ }^{4}$. DNA fragmentation factor (DFF) has a crucial role in DNA cleavage during the apoptotic process. DFF is a heterodimer of two subunits - catalytic subunit (DFF40) and regulatory subunit (DFF45) ${ }^{5}$. During apoptosis, activated caspase 3 cleaves the complex DFF45DFF40 leading to DFF40 activation ${ }^{6}$. Activated DFF40 cleaves double-stranded DNA with a preference for $A / T$ rich region ${ }^{7}$. DNA is cleaved in internucleosomal linker regions into approx. $180 \mathrm{bp}$ fragments and multiples thereof ${ }^{1}$. This characteristic DNA cleavage pattern is called "DNA ladder" and can be used for detection of apoptotic DNA fragmentation $1,8,9$. In addition to DNA ladder, comet and TUNEL assays belong among frequently used methods detecting apoptotic DNA fragmentation.

DNA ladder and comet assay belong to electrophoretic methods. DNA ladder assay uses the presence of the DNA ladder pattern of DNA fragments occurring during apoptosis detected after electrophoresis in agarose gel. Comet assay, also known as Single cell gel electrophoresis assay (SCGE), has been used for detection of single and double-strand DNA breaks. In the Terminal deoxynUcleotidyl transferase Nick-End Labeling (TUNEL) technique, free -OH moiety in the double and single strand DNA breaks is labeled using modified analogues of deoxynucleotides tagged with various markers allowing DNA strand breaks 
detection ${ }^{10}$. The chromatin condensation and DNA fragmentation can be also characterized using microscopic methods, especially using fluorescence microscopy. Fluorescent dyes, i.e. Hoechst ${ }^{11}$, DAPI 12 or Syto ${ }^{13}$ can be used for nuclear visualization as well.

Hoechst probes originate from bisbenzimides, a family of lipophilic substances, that bind preferentially to a small groove of adenine and thymine rich DNA sequences called A-T regions ${ }^{14}$. At least three consecutive A-T base pairs are required for specific Hoechst dye binding which leads to fluorescence increase. In addition, some papers reported that the nucleus of apoptotic cells can exhibit enhanced fluorescence after Hoechst binding ${ }^{15-17}$. Therefore, Hoechst probes have been frequently used for nucleus staining in fluorescence microscopy and flow cytometry ${ }^{18-20}$.

At present, three Hoechst probes have been used in vitro: $33258^{21}, 33342^{22}, 34580^{23}$. Hoechst 33258 has been most frequently used in fluorescence microscopy for qualitative detection of nuclear morphology changes, primarily for detecting cell shrinkage, chromatin condensation, nuclear fragmentation and apoptotic bodies formation in various cell lines ${ }^{24-28}$. Despite the unique properties of Hoechst probes used for detection of nuclear changes, no scientific study, however, has been reported on the development of a quantitative spectrofluorometric method. Thus, the aim of present study was to develop a spectrofluorometric assay using the Hoechst 33258 dye for quantitative measurement of nuclear condensation and fragmentation in intact cells. Finally, we aimed to evaluate the outcomes obtained using the developed spectrofluorometric assay in comparison with other frequently used methods detecting apoptotic processes.

\section{Results}

\subsection{Optimization of the spectrofluorometric assay}

We aimed to develop a spectrofluorometric method for detection of nuclear condensation and fragmentation in intact cells using a fluorescent probe Hoechst 33258. According to the literature, we confirmed that $\lambda_{(e x, \text { max })}$ and $\lambda_{(e m, \max )}$ of $\mathrm{H} 33258$ are 352 and $461 \mathrm{~nm}$, respectively ${ }^{29-31}$. Thus, we used those wavelengths in our study. We optimized the experimental procedure, i.e. H33258 concentration and length of incubation of the probe with cells. To induce cell damage, we incubated HepG2 cells with 100 $\mu \mathrm{M}$ CisPt for $24 \mathrm{~h}$. Then, we incubated the cells with range of concentrations $0.1-5 \mu \mathrm{g} / \mathrm{mL} \mathrm{H} 33258$ (Fig. 1A). The highest fluorescence signal was detected in $5 \mu \mathrm{g} / \mathrm{mL} \mathrm{H33258} \mathrm{in} \mathrm{CisPt} \mathrm{treated} \mathrm{cells} \mathrm{but} \mathrm{the}$ background fluorescence in untreated HepG2 cells was strongly enhanced too. Hence, we selected 2 $\mu \mathrm{g} / \mathrm{mL} \mathrm{H} 33258$ to be optimal for following experiments.

For estimating optimal incubation time of cells with $\mathrm{H} 33258$, HepG2 cells were treated with CisPt $(0 ; 50$; $100 \mu \mathrm{M})$ for $24 \mathrm{~h}$. We found that centrifugation of cells ( $5 \mathrm{~min}, 8,000 \mathrm{~g}, \mathrm{RT})$ after treatment with tested compounds followed by replacement of cell culture medium is crucial for achieving repeatable results because it ensures the sedimentation of all cells on the bottom of a well. After centrifugation, therefore, 
$70 \mu \mathrm{L}$ of culture medium was replaced with $70 \mu \mathrm{L}$ of PBS $1 \mathrm{x}$ in each well. Then, $10 \mu \mathrm{L}$ of H33258 was added to obtain final concentration $2 \mu \mathrm{g} / \mathrm{mL} \mathrm{H33258}$ in a well and fluorescence was recorded at $\mathrm{EX} / \mathrm{EM}=$ $352 / 461 \mathrm{~nm}$.

We found that fluorescence intensity was increasing strongly during the first minute of incubation of cells with H33258 (Fig. 1B). Then, the fluorescence intensity (IF) remained rather stable until the 10th minute. In addition, we confirmed that IF was enhanced relatively to the increasing CisPt concentration in cells according to expected induction of nuclear condensation and fragmentation. Thus, we selected 5 minutes to be an optimal duration of H33258 incubation with cells in all following experiments. Figure 1C shows IF detected in cells after subtraction of background fluorescence intensity in blank samples (i.e. without cells). Finally, IF in CisPt treated and untreated cells was calculated (Fig. 1D) and the extent of nuclear condensation and fragmentation in cells was expressed in Relative Fluorescence Units (RFU).

\subsection{Estimating sensitivity of the spectrofluorometric assay}

Further aim of our study was to use the H33258 spectrofluorometric assay in cells exhibiting nuclear condensation and fragmentation of different origin and extent. We incubated HepG2 and HK2 cells with CisPt (0; 0.5; 5; 25 and $100 \mu \mathrm{M})$ for 24 and $48 \mathrm{~h}$. After H33258 treatment, we observed increasing IF relating to both CisPt doses and incubation time in HepG2 (Fig. 2A) and HK2 cells (Fig. 2B). We found a significant increase of IF in 25 and $100 \mu \mathrm{M}$ CisPt treated cells after 24 and $48 \mathrm{~h}$. In addition, the extent of condensation and fragmentation was detected to be increased in comparison of $24 \mathrm{~h}$ and $48 \mathrm{~h}$ treatments at those concentrations (Figs. 2A, 2B).

We used two additional biochemical assays to characterize CisPt toxicity in cells, i.e. the WST-1 test detecting intracellular dehydrogenase activity and glutathione assay. We found that the dehydrogenase activity was considerably reduced in HepG2 and HK-2 cells treated with $\geq 5 \mu \mathrm{M}$ CisPt (Fig. $2 \mathrm{C}$ ) and $\geq 0.5$ $\mu \mathrm{M}$ CisPt (Fig. 2D), respectively, for $24 \mathrm{~h}$. On the other hand, the HK-2 cell line exhibited lower susceptibility to glutathione depletion than HepG2 cells because a significant reduction of glutathione levels was found only at concentrations $\geq 25 \mu \mathrm{M}$ CisPt (Figs. 2E, 2F). In conclusion, the outcomes found using the WST-1 and glutathione assays confirmed the occurrence of CisPt toxicity detected using the H33258 spectrofluorometric assay. According to our assumptions, the outcomes of WST-1 and glutathione assays detected cellular damage also in cells treated with lower concentrations of CisPt than the H33258 assay because the nuclear condensation and fragmentation can follow foregoing cell impairment.

In addition to CisPt, we aimed to utilize the spectrofluorometric assay for detection of nuclear changes in cells treated with other apoptotic inducers. Thus, we incubated HepG2 and HK2 cells with camptothecin (CAM, 1; $5 \mu \mathrm{M}$ ) and staurosporine (STA, 10; $100 \mathrm{nM}$ ) for 6, 24 and $48 \mathrm{~h}$ (Figs. 3A, 3B). To compare the results, we used CisPt as a positive control and $10 \mu \mathrm{g} / \mathrm{mL} \mathrm{TiO}{ }_{2}$ P25 nanoparticles as a negative control. Our results showed that we detected a significant increase of nuclear condensation and fragmentation in all tested compounds except of $\mathrm{TiO}_{2} \mathrm{P} 25$ nanoparticles which did not induce any detected nuclear changes at all tested time durations. After $6 \mathrm{~h}$ of treatment, we found a significant increase of IF related 
to enhanced nuclear changes only in HK-2 cells treated with $5 \mu \mathrm{M} \mathrm{CAM}(p<0.001)$. At $24 \mathrm{~h}$, a significant increase of nuclear condensation and fragmentation comparing with untreated cells was detected in all HK-2 treated cells with exception of $1 \mu \mathrm{M} \mathrm{CAM}(p=0.198)$ and $10 \mathrm{nM} \mathrm{STA}(p=0.999)$. We also found a significant increase of IF in HepG2 cells treated with higher concentrations of used apoptotic inducers. Thus, the H33258 assay did not detect a significant nuclear condensation and fragmentation in $1 \mu \mathrm{M}$ $\operatorname{CAM}(p=0.935), 10 \mathrm{nM}$ STA $(p=0.135)$ and $50 \mu \mathrm{M}$ CisPt $(p=0.382)$ treated HepG2 cells for $24 \mathrm{~h}$.

After $48 \mathrm{~h}$ of treatment, we found significantly increased extent of nuclear condensation in almost all tested concentrations of compounds in both cell lines. The only exception was observed in $10 \mathrm{nM} \mathrm{STA}$ treated HepG2 cells $(p=0.999)$ which exhibited a decrease of IF in comparison with $10 \mathrm{nM}$ STA treated cells for $24 \mathrm{~h}$. All tested concentrations of pro-apoptotic compounds induced larger nuclear condensation after $48 \mathrm{~h}$ incubation in comparison to $24 \mathrm{~h}$ and the cells treated with higher concentrations of tested compounds exhibited larger nuclear impairment in comparison to lower dose. The highest IF signal was detected in HepG2 and HK-2 cells treated with $100 \mu \mathrm{M}$ CisPt and $5 \mu \mathrm{M}$ CAM at $48 \mathrm{~h}$. In conclusion, our results confirmed that the $\mathrm{H} 33258$ spectrofluorometric assay was capable to detect increased nuclear condensation and fragmentation in all tested apoptotic inducers relatively to concentration and incubation period (Figs. 3A, 3B).

\subsection{Comparison of H33258 spectrofluorometric assay with apoptosis detecting methods}

To evaluate the outcomes of newly developed H33258 spectrofluorometric assay, we aimed to compare the results with other methods characterizing proapoptotic processes in cells. Therefore, we treated HepG2 and HK2 cells with CisPt (50 and $100 \mu \mathrm{M}$ ) for 6, 24 and $48 \mathrm{~h}$ and characterized nuclear changes and proapoptotic activation using four additional measurements, i.e. caspase $3 / 7$ activity, PARP-1 and JNK proteins expression, TUNEL assay and DNA ladder.

We measured the activity of caspases 3 and 7 to evaluate apoptotic activation in the cells. Despite detecting a significant increase in caspase $3 / 7$ activity in both cell lines treated with $100 \mu \mathrm{M}$ CisPt for $6 \mathrm{~h}$, the largest enhancement of caspase $3 / 7$ activity was detected in cells treated with $50 \mu \mathrm{M}$ CisPt for $24 \mathrm{~h}$ (Fig. 4). At 48 h, the caspase 3/7 activities remained increased although we found a decrease in comparison to cells treated for $24 \mathrm{~h}$.

Then, we analyzed the levels of PARP-1, PARP-1 fragment (fPARP-1), pJNK and $\beta$-actin. PARP1 protein serves as a substrate for caspase 3 during apoptosis. Thus, PARP1 cleavage leading to fPARP-1 production is related to the extent of caspase 3 activation. After $24 \mathrm{~h}$ of treatment, we detected PARP-1 fragmentation in cells treated with both concentrations of cisplatin which persisted until $48 \mathrm{~h}$ only in HepG2 cells (Table 1). Phosphorylation of JNK1 and JNK2 can also correspond with activated apoptotic process and that is why we aimed to estimate their levels. We observed that pJNK1 levels were increased in all tested time incubation with CisPt in HepG2 cells. In HK-2 cells, protein expressions of pJNK1 and pJNK2 were stimulated predominantly at $24 \mathrm{~h}$ of treatment. Thus, the detected increase of pJNK levels correlated strongly with PARP fragmentation in both cell lines. 
Table 1

PARP and JNK protein expressions in CisPt treated cells.

\begin{tabular}{|c|c|c|c|c|c|c|c|c|c|}
\hline & & HepG2 & & & & HK-2 & & & \\
\hline Time & $\begin{array}{l}\text { CisPt } \\
{[\mu \mathrm{M}]}\end{array}$ & PARP-1 & fPARP-1 & pJNK1 & pJNK2 & PARP-1 & fPARP-1 & pJNK1 & pJNK2 \\
\hline \multirow[t]{3}{*}{$6 \mathrm{~h}$} & 0 & 2.3 & 0 & 0 & 0 & 0.4 & 0.1 & 0 & 0 \\
\hline & 50 & 2.3 & 0 & 0.2 & 0.2 & 0.9 & 0.1 & 0 & 0 \\
\hline & 100 & 1.8 & 0 & 0.4 & 0.3 & 0.7 & 0.5 & 0.1 & 0.1 \\
\hline \multirow[t]{3}{*}{$24 \mathrm{~h}$} & 0 & 1.9 & 0 & 0 & 0 & 1.6 & 0.1 & 0.1 & 0 \\
\hline & 50 & 1.9 & 1.3 & 0.2 & 0.2 & 0.9 & 1.5 & 0.2 & 0.1 \\
\hline & 100 & 2.7 & 2.0 & 0.7 & 0.6 & 0.8 & 1.5 & 0.3 & 0.2 \\
\hline \multirow[t]{3}{*}{$48 \mathrm{~h}$} & 0 & 3.0 & 0 & 0 & 0 & 0.9 & 0 & 0 & 0 \\
\hline & 50 & 3.2 & 1.3 & 0.5 & 0 & 0.9 & 0.1 & 0 & 0 \\
\hline & 100 & 3.2 & 1.0 & 1.2 & 1.0 & 0 & 0 & 0 & 0 \\
\hline
\end{tabular}

HepG2 and HK-2 cells were treated with CisPt (50 and $100 \mu \mathrm{M}$ ) for 6, 24 and $48 \mathrm{~h}$. After incubation, the protein expression of PARP-1, fPARP-1, pJNK1 and pJNK2 was analyzed using capillary western immunoassay. The results were expressed as a ratio: $\frac{\text { area of the peak of interest }}{\text { area of the peak of } \beta \text {-actin }}$

TUNEL assay was used for detection of DNA strand breaks in CisPt treated cells (Fig. 5). After $6 \mathrm{~h}$ of treatment, a week fluorescence demonstrating presence of DNA strand breaks was observed only in 100 $\mu \mathrm{M}$ CisPt treated HepG2 cells. At longer time durations, TUNEL staining detected strong DNA fragmentation in both cell lines treated with both 50 and $100 \mu \mathrm{M}$ CisPt (Fig. 5).

At final, we used DNA ladder assay in CisPt treated cells to estimate the extent of DNA fragmentation. The internucleosomal DNA fragmentation can occur as the terminal feature of apoptosis. Thus, we detected DNA ladder pattern only in CisPt treated HepG2 cells after $48 \mathrm{~h}$ (Fig. 6A) and in HK-2 cells after 24 and 48 h (Fig. 6B).

We summarized and compared the results obtained using all methods detecting apoptosis in CisPt treated HepG2 and HK-2 cells (Table 2). We proved that the initial increase in caspase 3/7 activity was followed by fragmentation of PARP-1, DNA fragmentation detected using TUNEL assay and formation of DNA ladder. In addition, Table 2 shows that the newly developed spectrofluorometric assay using the H33258 dye provided outcomes fully comparable with TUNEL assay which has been used as a standard method detecting increased levels of DNA fragmentation in cells. 
Table 2

Comparison of assays detecting proapoptotic changes.

\begin{tabular}{|c|c|c|c|c|c|c|}
\hline & & H33258 & Caspases & TUNEL & fPARP-1 & DNA ladder \\
\hline \multirow[t]{2}{*}{$6 \mathrm{~h}$} & HepG2 & + & + & $+/-$ & - & - \\
\hline & HK-2 & - & ++ & - & + & - \\
\hline \multirow[t]{2}{*}{$24 \mathrm{~h}$} & HepG2 & ++ & ++ & ++ & ++ & - \\
\hline & HK-2 & ++ & ++ & ++ & ++ & ++ \\
\hline \multirow[t]{2}{*}{$48 \mathrm{~h}$} & HepG2 & ++ & ++ & ++ & ++ & ++ \\
\hline & HK-2 & ++ & - & ++ & - & ++ \\
\hline
\end{tabular}

HepG2 and HK-2 cells were treated with $100 \mu \mathrm{M}$ CisPt for 6, 24 and $48 \mathrm{~h}$. After treatment, the nuclear changes were detected using five methods, i.e. developed spectrofluorometric assay using Hoechst 33258 (= H33258), caspase 3/7 activity, TUNEL assay, protein expression of PARP-1 fragment (fPARP-1) and DNA ladder. (-, negative; +/-, moderately positive; +, positive; ++, strongly positive).

\section{Discussion}

DNA staining using Hoechst fluorescent probes belongs to commonly used approaches for visual detection of nuclear condensation. Three probes have been frequently used for nuclear staining in cells: Hoechst $33342^{11,22}, 34580^{23}$ or $33258^{21}$. Hoechst 33342 has been mostly used for flow cytometry ${ }^{32-}$

34 . On the other hand, H33258 staining has been predominantly used in fluorescence microscopy 18,19,35. To compare both Hoechst probes, a study reported larger toxicity of $\mathrm{H} 33342$ than $\mathrm{H} 33258{ }^{36}$. Recent scientific studies have described the use of $\mathrm{H} 33258$ for fluorescence detection of cell shrinkage, chromatin condensation, nuclear fragmentation and apoptotic bodies formation in cells ${ }^{15,24-28}$. Surprisingly, these reports used H33258 only for microscopic detection of nuclear changes. Thus, we aimed to develop a quantitative spectrofluorometric method for the detection of nuclear condensation and fragmentation using $\mathrm{H} 33258$ in cultured cells.

Firstly, we optimized H33258 concentration which is of crucial importance due to potential toxicity of the dye. Some studies reported that H33258 levels higher than $5 \mu \mathrm{g} / \mathrm{mL}$ are toxic to cells especially after long-term exposure ${ }^{37,38}$. H33258 concentration used in studies has been $1-5 \mu \mathrm{g} / \mathrm{mL} \mathrm{H33258}$ in fluorescence microscopy ${ }^{39,40}$ and $0.5-2 \mu \mathrm{g} / \mathrm{mL}$ H33258 in flow cytometry ${ }^{20,41,42}$. Therefore, we decided to estimate $\mathrm{H} 33258$ concentrations in the range of $0.1-5 \mu \mathrm{g} / \mathrm{mL}$ for development of the

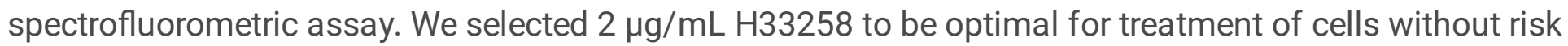
of cell impairment during the spectrofluorometric measurement for 5 min.

After introduction of the spectrofluorometric assay's conditions, we aimed to utilize the assay for detection of chromatin condensation and nuclear fragmentation in two cell lines of different origin, i.e. 
human liver carcinoma HepG2 cells and proximal tubular epithelial HK-2 cells, treated with three inducers of apoptosis (cisplatin, camptothecin, staurosporine). Cisplatin is an anticancer drug used for malignant tumor treatment. It is capable to induce apoptosis and apoptotic DNA fragmentation in cells ${ }^{43,44}$ as well as camptothecin 45,46 . Staurosporine is a strong inhibitor of protein kinases inducing apoptosis and DNA fragmentation ${ }^{47,48}$. Moreover, the cells were incubated with $\mathrm{TiO}_{2} \mathrm{P} 25$ nanoparticles which have been reported to possess no capability to induce nuclear condensation or DNA fragmentation in HepG2 cells 49 .

According to our results, we showed that the developed spectrofluorometric assay using H33258 was capable to detect nuclear changes. In addition, the intensity of fluorescence reflected different extent of nuclear condensation and fragmentation in comparison of 6,24 and $48 \mathrm{~h}$ of incubation in CAM, STA and CisPt treated cells. Our finding of nuclear condensation and fragmentation detected using the new spectrofluorometric method after treatment with $5 \mu \mathrm{M}$ CAM for $6 \mathrm{~h}$ can be supported by a study of Rath et al. ${ }^{46}$ who found presence of apoptotic nuclei in $5 \mu \mathrm{M}$ CAM treated thyroid carcinoma cells after $8 \mathrm{~h}$ of treatment using TUNEL assay. Another study focused on estimation of CAM-dependent induction of apoptosis showed occurrence of apoptotic changes in $1 \mu \mathrm{M}$ CAM treated HepG2 cells after $24 \mathrm{~h}^{50}$ using flow cytometry. Therefore, the newly developed H33258 spectrofluorometric method provided similar outcomes to other scientific reports studying apoptosis induced by camptothecin .

To characterize staurosporine effect in cells, we used the concentrations which have been reported to be sufficient to induce the cell death 47,51 . Our results on detection of changes in nuclear structure using the spectrofluorometric method are consistent with a study of Ding et al. ${ }^{47}$ who also detected DNA fragmentation in $10 \mathrm{nM}$ STA treated HepG2 cells after $24 \mathrm{~h}$ of treatment using TUNEL assay. Another paper of Deshmuk and Johnson ${ }^{48}$ described a finding of increased DNA fragmentation in $100 \mathrm{nM}$ STA treated sympathetic neurons after $24 \mathrm{~h}$ using TUNEL staining as well. Therefore, we can conclude again that the spectrofluorometric method using H33258 provided results similar to the outcomes of other studies characterizing staurosporine action in cells.

Finally, we aimed to use the spectrofluorometric assay using the H33258 dye for characterization of cisplatin action in cells and to compare obtained results with the outcomes of other apoptosis detecting assays. Occurrence of significant pro-apoptotic nuclear changes in cisplatin-treated cells has been broadly reported after $24 \mathrm{~h}$ of incubation. A study of Yang et al. ${ }^{44}$ detected increased DNA fragmentation in $50 \mu \mathrm{M}$ CisPt treated HK-2 cells for $24 \mathrm{~h}$ using TUNEL assay. Similar results were obtained also in CisPt treated LLC-PK1 kidney cells using TUNEL assay ${ }^{52}$ and in HepG2 cells using fluorescence microscopy and flow cytometry ${ }^{43}$. Based on these papers, our findings of increased nuclear condensation and fragmentation in 50 and $100 \mu \mathrm{M}$ CisPt treated HepG2 and HK-2 cells using the developed spectrofluorometric assay are fully consistent with the literature.

The latter goal of our study was to compare the outcomes obtained using the developed spectrofluorometric assay in CisPt treated cells with outcomes of other, frequently used assays detecting 
apoptosis, i.e. caspase 3/7 activity, JNK/PARP proteins expression, TUNEL assay and DNA ladder. Caspase $3 / 7$ activation detected in our experiments after $6 \mathrm{~h}$ of treament was also described in a paper of Schweyer et al. ${ }^{53}$ in $50 \mu \mathrm{M}$ CisPt treated NCCIT cells. Persisting activation of caspases 3/7 was reported in a number of studies, e.g. in UBOC1, HK-2 and SH-SY5Y cells after treatment with 5,10 a $20 \mu \mathrm{M}$ CisPt for $24 \mathrm{~h}^{54}$ and in HepG2 cells treated with $25 \mu \mathrm{M}$ CisPt for 12,24 and $48 \mathrm{~h}{ }^{55}$.

Capillary Western immunoassay was performed for detection of protein expression changes of PARP1, JNK1 and JNK2. PARP-1 reflects the extent of DNA damage ${ }^{56}$ because it is cleaved by caspases-3/7 to two specific fragments of 24 and $89 \mathrm{kDa}{ }^{57}$. Thus, cleavage of PARP-1 protein by caspases is usually mentioned to be a hallmark of apoptosis ${ }^{58}$. Our results on detecting PARP-1 cleavage after treatment with $50 \mu \mathrm{M}$ CisPt for $24 \mathrm{~h}$ are similar to the study of Ju et al. ${ }^{59}$ who detected the PARP-1 cleavage in HK2 cells treated with $40 \mu \mathrm{M}$ CisPt for $24 \mathrm{~h}$. JNKs were reported to be strongly activated via phosphorylation in cells incubated with cisplatin ${ }^{60}$. In our study, expression of phosphorylated JNK isoforms (JNK1 and JNK2) was elevated after cisplatin treatment in all time intervals in dose-dependent manner compared to control cells which is similar to reported finding on increased pJNK expression in HeLa cells after incubation with 50 and $100 \mu \mathrm{M}$ CisPt for $6 \mathrm{~h}^{61}$, and in pig kidney epithelial cells after $25 \mu \mathrm{M}$ CisPt treatment for $24 \mathrm{~h}^{62}$.

Finally, TUNEL and DNA ladder assays were performed in CisPt treated cells. Both assays belong among frequently used methods for detection of DNA strand breaks and fragmentation ${ }^{10,44}$.

We found that TUNEL assay detected DNA fragmentation after $24 \mathrm{~h}$ of CisPt treatment. Thus, we obtained similar results to finding on DNA fragmentation detected using TUNEL assay in $50 \mu \mathrm{M} \mathrm{CisPt}$ treated HK-2 cells ${ }^{44}$ and LLC-PK1 cells ${ }^{52}$ after $24 \mathrm{~h}$. The detection of internucleosomal DNA fragments using DNA ladder assay is in accordance with outcomes of studies of Qin et al. (2002) and Lau 63 reporting occurrence of DNA ladder in CisPt treated HepG2 and LLC-PK1 cells after 24 and $48 \mathrm{~h}$. We summarize that the findings of DNA fragmentation and nuclear condensation detected using all the biochemical assays in HepG2 and HK-2 cells after cisplatin treatment presented in this study are in accordance to published reports of other authors testing cisplatin as well.

\section{Conclusion}

We developed a spectrofluorometric method using Hoechst 33258 staining which detects nuclear condensation and fragmentation in intact cells. Our results showed that the spectrofluorometric method was capable to detect the nuclear changes in three typical pro-apoptotic agents, i.e. cisplatin, camptothecin, staurosporine, and in two cell lines of different origin. In addition, we compared the results obtained using the spectrofluorometric assay with outcomes of other methods characterizing apoptotic processes. Based on this comparison, we conclude that here developed spectrofluorometric method is capable to detect nuclear proapoptotic changes of similar sensitivity and specificity to that of caspase $3 / 7$ activity measurement and TUNEL assay. Therefore, we suppose that the spectrofluorimetric H33258 
method could join other routinely used methods characterizing apoptosis in cells. In comparison to TUNEL assay, the developed spectrofluorometric assay possesses several advantages (e.g. rapid processing, quantitative evaluation, low-cost) implying its potential use in assessing nuclear condensation and fragmentation in routine laboratory practice and in high-throughput screening studies.

\section{Materials And Methods}

\section{Chemicals}

Hoechst 33258 solution (H33258, $1 \mathrm{mg} / \mathrm{mL}$ ) and all other chemicals (formaldehyde, Triton X-100, BSA, $\mathrm{NaCl}, \mathrm{NaOH}$, Tris base, $\mathrm{Na}_{2} \mathrm{EDTA} \cdot 2 \mathrm{H}_{2} \mathrm{O}$, PBS 10x, cisplatin, staurosporine, camptothecin, $\mathrm{TiO}_{2} \mathrm{P} 25$ ) were purchased from Sigma Aldrich, USA.

\section{Cell culture and treatment}

All materials for cell culture were purchased from Sigma-Aldrich (USA) if not otherwise specified. HepG2 cells (ATCC $\left.\circledast \mathrm{HB}-8065^{\mathrm{TM}}\right)$, a human hepatocellular carcinoma cell line, were purchased from ATCC (Manassas, VA, USA). HepG2 cells were cultured in Dulbecco's Modified Eagle's Medium with high glucose content $(4500 \mathrm{~g} / \mathrm{L}$, w/wo phenol red) supplemented with $10 \%(\mathrm{v} / \mathrm{v})$ fetal bovine serum, $50 \mathrm{\mu g} / \mathrm{mL}$ penicillin, $50 \mu \mathrm{g} / \mathrm{mL}$ streptomycin, $10 \mathrm{mM}$ HEPES and $2 \mathrm{mM}$ glutamine, maintained at $37^{\circ} \mathrm{C}$ in a sterile, humidified atmosphere of $5 \% \mathrm{CO}_{2}$. All the experiments were conducted using $\mathrm{HepG} 2$ cells in passages 415.

Human kidney, HK-2 cells (ATCC $® \mathrm{CRL}-2190^{\mathrm{TM}}$ ), a proximal tubular epithelial cell line derived from normal adult human kidney cells immortalized by transduction with human papillomavirus (HPV 16) DNA fragment ${ }^{64}$, were purchased from the ATCC (Manassas, VA, USA). The cells were cultured in supplemented Dulbecco's modified Eagle's medium (DMEM/F12 $=1: 1$ ) with $5 \%(\mathrm{v} / \mathrm{v})$ fetal bovine serum, 1 $\mathrm{mM}$ pyruvate, $10 \mu \mathrm{g} / \mathrm{mL}$ insulin, $5.5 \mu \mathrm{g} / \mathrm{mL}$ transferrin, $5 \mathrm{ng} / \mathrm{mL}$ sodium selenite, $50 \mu \mathrm{g} / \mathrm{mL}$ penicillin, 50

$\mu \mathrm{g} / \mathrm{mL}$ streptomycin, and $5 \mathrm{ng} / \mathrm{mL}$ epidermal growth factor according to a published protocol ${ }^{65,66}$. All the experiments were conducted using the HK-2 cells in passages 5-15.

HepG2 and HK-2 cells were tested for mycoplasma contamination using the MycoAlert Mycoplasma Detection Kit (Lonza). All cells used in the experiments were mycoplasma free. Short tandem repeat (STR) analysis (i.e., DNA fingerprinting) was used for HepG2 and HK-2 cell line authentication using a commercial kit in Generi Biotech (Czech Republic). The STR analysis proved $100 \%$ conformity of both HepG2 and HK-2 cells with the reference standards.

The HepG2 and HK-2 cells were seeded in $100 \mu \mathrm{L}$ of appropriate cell culture medium in 96-well plates at density of $1.5 \times 10^{4}$ and $2 \times 10^{4}$ cells per well for $24 \mathrm{~h}$ (if not stated otherwise). To induce cell impairment, we used: cisplatin (CisPt, 0-100 $\mu \mathrm{M}$ ), camptothecin (CAM; 0-5 $\mu \mathrm{M}$ ), staurosporine (STA; 0-100 nM) and $\mathrm{TiO}_{2} \mathrm{P} 25$ nanoparticles (NPs; $0-10 \mu \mathrm{g} / \mathrm{mL}$ ). All compounds were diluted in appropriate cell culture mediums to obtain final concentrations. After seeding, the culture medium was replaced by $100 \mu \mathrm{L}$ of 
medium containing a tested compound and the cells were treated for 6,24 and $48 \mathrm{~h}$. To characterize the extent of cell impairment, we used the newly developed spectrofluorometric assay using H33258 together with caspase activity and proteins expression measurements, TUNEL and DNA ladder assays.

\section{Hoechst 33258 spectrofluorometric assay}

To develop a spectrofluorometric method for detection of changes in nuclear condensation and fragmentation in intact cells, we used a fluorescence dye H33258. To optimize the assay, we used HepG2 and HK-2 cells at confluency $50-70 \%$. After treatment with tested compounds (CisPt, CAM, STA, NPs) for 6,24 and $48 \mathrm{~h}$, the cells grown in a 96well plate were centrifuged ( $5 \mathrm{~min}, 8000 \mathrm{~g}$ ) at RT. Then, $70 \mu \mathrm{L}$ of a supernatant was replaced with $70 \mu \mathrm{L}$ of warmed phosphate-buffered saline (PBS $1 \mathrm{x}, 37^{\circ} \mathrm{C}$ ) and $10 \mu \mathrm{L}$ of H33258 solution (in PBS 1x) was added to a well. The final concentrations of H33258 in a well were 0.1-5 $\mu \mathrm{g} / \mathrm{mL}$. Then, the cells were incubated with $\mathrm{H} 33258$ for 60 minutes during optimization of the assay, or for $5 \mathrm{~min}$ at optimal conditions and the spectrofluorometric measurement was performed at EX/EM = $352 / 461 \mathrm{~nm}$ (EX/EM slit widths 25/25 nm) using a Tecan Spark fluorescence microplate reader (Tecan, Switzerland) while incubated at $37^{\circ} \mathrm{C}$. The samples were measured at least in triplicates. After background subtraction, the fluorescence signal was presented in Relative Fluorescence Units (RFU) as mean \pm SEM. All spectrofluorometric measurements presented here were repeated at least in three independent experiments.

\section{Dehydrogenase activity measurement}

Dehydrogenase activity was evaluated by WST-1 test (Roche, Germany). The WST-1 test measures the activity of intra- and extramitochondrial dehydrogenases. After cell treatment, $10 \mu \mathrm{L}$ of WST-1 reagent was added to the treated cells. The absorbance change $(0-1 \mathrm{~h})$ was measured spectrophotometrically at wavelength of $440 \mathrm{~nm}$ using a Tecan Spark fluorescence microplate reader (Tecan, Switzerland). The cell viability was expressed as the percentage of intra- and extramitochondrial dehydrogenases activity relative to that in control cells $(=100 \%)$. The results were expressed as mean \pm SD.

\section{Glutathione assay}

Glutathione levels were measured using the monochlorobimane spectrofluorometric assay ${ }^{67}$. After cell treatment, $20 \mu \mathrm{L}$ of the bimane solution was added to cells to obtain the final concentration $40 \mu \mathrm{M}$ and spectrofluorometric measurement was started immediately. The fluorescence increase (EX/EM = 394/490 $\mathrm{nm}$ ) was measured for 10 min using a Tecan Spark fluorescence microplate reader (Tecan, Switzerland). The fluorescence was expressed as the slope of change in fluorescence over time. The glutathione levels were expressed as the percentage relative to the glutathione levels in control cells $(=100 \%)$. The results were expressed as mean \pm SD.

\section{Caspase 3/7 activity measurement}


Caspase 3/7 activity in HepG2 and HK-2 cells was detected using ApoONE® Homogeneous Caspase-3/7 Assay (Promega, USA) according to the manufacturer's instructions. Briefly, $100 \mu \mathrm{L}$ of the caspase $3 / 7$ working solution was added to treated cells. After mixing, the cells were incubated for $30 \mathrm{~min}$. Then, the fluorescence $(E X / E M=485 / 535 \mathrm{~nm}$ ) was measured in duplicates using a Tecan Spark fluorescence microplate reader (Tecan, Switzerland) while incubated at $37^{\circ} \mathrm{C}$. The caspase $3 / 7$ activity levels were expressed as the percentage relative to the caspase $3 / 7$ activity levels in control cells $(=100 \%)$. The results were expressed as mean \pm SEM.

\section{Capillary Western Immunoassay}

Capillary Western Immunoassay was performed in protein lysates from HepG2 and HK-2 cells cultured in 6-well plates at density of $5 \times 10^{5}$ and $1.3 \times 10^{6}$ cells per well, respectively. After seeding, the culture medium was replaced by $2 \mathrm{~mL}$ of CisPt solution and the cells were treated for 6,24 and $48 \mathrm{~h}$. After treatment, the cells were washed twice with PBS $1 \mathrm{x}$ and protein lysates were prepared by lysing cells with $400 \mu \mathrm{L}$ of RIPA buffer (Sigma-Aldrich, USA) with MS-safe protease and phosphatase inhibitor (SigmaAldrich, USA) on ice. Capillary Western Immunoassay was performed according to manufacturer's instructions (Protein Simple, USA). Briefly, protein lysates were analyzed on a Wes system (ProteinSimple, USA) using a 12-230 kDa Separation Module (Biotechne, UK). Levels of phosphorylated JNK (pJNK, primary antibody 1:50, Promega, USA), poly-(ADP-ribose) polymerase-1 (PARP-1; primary antibody 1:100; Cell Signalling, USA) were normalized using the reference protein $\beta$-actin (primary antibody 1:500, SigmaAldrich, USA). The peaks were analyzed using Compass software (Protein Simple, USA). Two criteria were used for the discrimination of signals from the background: 1) the peak high must be higher or equal to 1000 and 2) the peak's signal-to-noise ratio given by the software must be higher or equal to 10 . The results were counted as: $\frac{\text { area of the peak of interest }}{\text { area of the peak of } \beta \text {-actin }}$

\section{TUNEL assay}

TUNEL assay followed by H33258 staining of nuclei was performed in HepG2 and HK-2 cells cultured in $200 \mu \mathrm{L}$ of appropriate cell culture medium on cell culture chamber slides at density of $1.5 \times 10^{5}$ and $2 \times 10^{5}$ cells per well, respectively. After seeding, the culture medium was replaced by $200 \mu \mathrm{L}$ of CisPt solutions and the cells were treated for 6,24 and $48 \mathrm{~h}$. TUNEL assay was performed using ClickiT ${ }^{\mathrm{TM}}$ TUNEL Alexa Fluor $^{\text {TM }} 488$ Imaging Assay kit (ThermoFisher Scientific, USA) according to manufacturer's instructions. The cells were fixed with $12 \%$ formaldehyde for $15 \mathrm{~min}$ at $37^{\circ} \mathrm{C}$. Then, the cells were permeabilized with $0.2 \%$ Triton $\mathrm{X}-100$ for $15 \mathrm{~min}$ at $37^{\circ} \mathrm{C}$, washed with PBS $1 \mathrm{x}$ and incubated with terminal deoxynucleotidyl transferase $(\mathrm{TdT})$ buffer for $10 \mathrm{~min}$ at $37^{\circ} \mathrm{C}$. After incubation, cells were mixed with a $\mathrm{TdT}$ reaction mixture (TdT buffer, 5-Ethynyl-2'-deoxyuridine $5^{\prime}$-triphosphate, $\mathrm{TdT}$ ) and incubated for $1 \mathrm{~h}$ at $37^{\circ} \mathrm{C}$. Then, the cells were washed with $3 \%$ bovine serum albumin (BSA) and Click IT reagent for fluorescent staining was added for $30 \mathrm{~min}$ at $37^{\circ} \mathrm{C}$. After PBS $1 \mathrm{x}$ washing, $\mathrm{H} 33258$ at a final concentration of $2 \mu \mathrm{g} / \mathrm{mL}$ was used to visualize the cell nuclei. DNA strand breaks (FITC filter, 480/30 nm) and cell nuclei (DAPI filter, $375 / 28 \mathrm{~nm}$ ) were visualized with an Eclipse 80i fluorescence microscope (Nikon, Japan). 
DNA ladder was performed in HepG2 and HK-2 cells cultured in 6-well plates at density of $5 \times 10^{5}$ and $1 \times 10^{6}$ cells per well, respectively. After seeding, the culture medium was replaced by $2 \mathrm{~mL}$ of CisPt and the cells were treated for 6, 24 and 48 h. DNA was isolated from treated cells using The ApoTarget ${ }^{\mathrm{TM}}$ Quick Apoptotic DNA Ladder Detection Kit (Invitrogen, USA). Isolated DNA samples were loaded onto a $1.5 \%$ agarose gel with $0.5 \mathrm{mg} / \mathrm{mL}$ ethidium bromide (Top-Bio, Czech Republic) followed by electrophoresis (5 $\mathrm{V} / \mathrm{cm}$ ). Finally, DNA was visualized by an ultraviolet gel documentation system (Vilber Lourmat, Germany) at wavelength $254 \mathrm{~nm}$. GeneRuler 100 bp DNA ladder (ThermoFisher Scientific, USA) was used as a DNA size standard.

Statistical analysis

Statistical analysis was performed using OriginPro 9.0.0 (OriginLab, USA). Statistical significance was analyzed after normality testing using one-way analysis of variance (ANOVA) followed by Tukey's test at significance level $p=0.05$ ( $*, p<0.05 ; * \star, p<0.01 ; * \star *, p<0.001)$.

\section{Declarations}

\section{Funding}

The financial support was received from the Ministry of Education, Youth and Sports of the Czech Republic via projects NANOBIO (Reg. No. CZ.02.1.01/0.0/0.0/17_048/0007421).

\section{Competing interests}

The author(s) declare no competing interests.

\section{References}

1. Wyllie, A. H. Glucocorticoid-induced thymocyte apoptosis is associated with endogenous endonuclease activation. Nature 284, 555-556, doi:10.1038/284555a0 (1980).

2. Elmore, S. Apoptosis: a review of programmed cell death. Toxicol Patho/35, 495-516, doi:10.1080/01926230701320337 (2007).

3. Caruso, S. et al. Defining the role of cytoskeletal components in the formation of apoptopodia and apoptotic bodies during apoptosis. Apoptosis 24, 862-877, doi:10.1007/s10495-019-01565-5 (2019).

4. Ferri, K. F. \& Kroemer, G. Control of apoptotic DNA degradation. Nat Cell Bio/2, E63-64, doi:10.1038/35008692 (2000).

5. Liu, X., Zou, H., Slaughter, C. \& Wang, X. DFF, a heterodimeric protein that functions downstream of caspase-3 to trigger DNA fragmentation during apoptosis. Cel/ 89, 175-184, doi:10.1016/s0092- 
8674(00)80197-x (1997).

6. Zhou, P., Lugovskoy, A. A., McCarty, J. S., Li, P. \& Wagner, G. Solution structure of DFF40 and DFF45 $\mathrm{N}$-terminal domain complex and mutual chaperone activity of DFF40 and DFF45. Proc Natl Acad Sci U S A 98, 6051-6055, doi:10.1073/pnas.111145098 (2001).

7. Nagata, S., Nagase, H., Kawane, K., Mukae, N. \& Fukuyama, H. Degradation of chromosomal DNA during apoptosis. Cell Death Differ 10, 108-116, doi:10.1038/sj.cdd.4401161 (2003).

8. Skalka, M., Matyasova, J. \& Cejkova, M. Dna in chromatin of irradiated lymphoid tissues degrades in vivo into regular fragments. FEBS Lett 72, 271-274, doi:10.1016/0014-5793(76)80984-2 (1976).

9. Pariente, R., Pariente, J. A., Rodríguez, A. B. \& Espino, J. Melatonin sensitizes human cervical cancer HeLa cells to cisplatin-induced cytotoxicity and apoptosis: effects on oxidative stress and DNA fragmentation. Journal of Pineal Research 60, 55-64, doi:10.1111/jpi.12288 (2016).

10. Majtnerová, P. \& Roušar, T. An overview of apoptosis assays detecting DNA fragmentation. Molecular Biology Reports 45, 1469-1478, doi:10.1007/s11033-018-4258-9 (2018).

11. Loken, M. R. Separation of viable T and B lymphocytes using a cytochemical stain, Hoechst 33342. J Histochem Cytochem 28, 36-39, doi:10.1177/28.1.6153191 (1980).

12. Morikawa, K. \& Yanagida, M. Visualization of individual DNA molecules in solution by light microscopy: DAPI staining method. J Biochem 89, 693-696, doi:10.1093/oxfordjournals.jbchem.a133247 (1981).

13. Wlodkowic, D., Skommer, J. \& Darzynkiewicz, Z. SYTO probes in the cytometry of tumor cell death. Cytometry A 73, 496-507, doi:10.1002/cyto.a.20535 (2008).

14. Martin, R. M., Leonhardt, H. \& Cardoso, M. C. DNA labeling in living cells. Cytometry A 67, 45-52, doi:10.1002/cyto.a.20172 (2005).

15. Zhang, X. T., Song, T. B., Du, B. L., Li, D. M. \& Li, X. M. Caspase-3 antisense oligodeoxynucleotides inhibit apoptosis in gamma-irradiated human leukemia HL-60 cells. Apoptosis 12, 743-751, doi:10.1007/s10495-006-0018-8 (2007).

16. Zhu, B. S. et al. Blocking NF-kappaB nuclear translocation leads to p53-related autophagy activation and cell apoptosis. World journal of gastroenterology 17, 478-487, doi:10.3748/wjg.v17.i4.478 (2011).

17. Shenker, B. J., Datar, S., Mansfield, K. \& Shapiro, I. M. Induction of apoptosis in human T-cells by organomercuric compounds: a flow cytometric analysis. Toxicol Appl Pharmaco/ 143, 397-406, doi:10.1006/taap.1997.8111 (1997).

18. Gomes, C. J., Harman, M. W., Centuori, S. M., Wolgemuth, C. W. \& Martinez, J. D. Measuring DNA content in live cells by fluorescence microscopy. Cell Div 13, 6, doi:10.1186/s13008-018-0039-z (2018).

19. Liu, C.-H., Tsao, M.-H., Sahoo, S. L. \& Wu, W.-C. Magnetic nanoparticles with fluorescence and affinity for DNA sensing and nucleus staining. RSC Advances 7, 5937-5947, doi:10.1039/c6ra25610d (2017). 
20. Carlson, C. R., Grallert, B., Bernander, R., Stokke, T. \& Boye, E. Measurement of nuclear DNA content in fission yeast by flow cytometry. Yeast 13, 1329-1335, doi:10.1002/(SICI)10970061(199711)13:14<1329::AID-YEA185>3.0.C0;2-M (1997).

21. Vardevanyan, P. O., Parsadanyan, M. A., Antonyan, A. P., Shahinyan, M. A. \& Karapetyan, A. T. Spectroscopic study of interaction of various GC-content DNA with Hoechst 33258 depending on $\mathrm{Na}(+)$ concentration. J Biomol Struct Dyn, 1-5, doi:10.1080/07391102.2020.1730244 (2020).

22. Campos, V., Rappaz, B., Kuttler, F., Turcatti, G. \& Naveiras, O. High-throughput, nonperturbing quantification of lipid droplets with digital holographic microscopy. J Lipid Res 59, 1301-1310, doi:10.1194/jlr.D085217 (2018).

23. Nogueira, E. et al. Assessment of liposome disruption to quantify drug delivery in vitro. Biochim Biophys Acta 1858, 163-167, doi:10.1016/j.bbamem.2015.11.008 (2016).

24. Qin, G. Q. et al. Dihydroartemisinin induces apoptosis preferentially via a Bim-mediated intrinsic pathway in hepatocarcinoma cells. Apoptosis 20, 1072-1086, doi:10.1007/s10495-015-1132-2 (2015).

25. Kapoor, R., Rizvi, F. \& Kakkar, P. Naringenin prevents high glucose-induced mitochondria-mediated apoptosis involving AIF, Endo-G and caspases. Apoptosis 18, 9-27, doi:10.1007/s10495-012-0781-7 (2013).

26. Chen, G. et al. Mammalian target of rapamycin regulates isoliquiritigenin-induced autophagic and apoptotic cell death in adenoid cystic carcinoma cells. Apoptosis 17, 90-101, doi:10.1007/s10495011-0658-1 (2012).

27. Soares, J. et al. Structure-cytotoxicity relationship profile of 13 synthetic cathinones in differentiated human SH-SY5Y neuronal cells. Neurotoxicology 75, 158-173, doi:10.1016/j.neuro.2019.08.009 (2019).

28. Zhang, Z. et al. Cytochrome P450 $2 \mathrm{~A} 13$ is an efficient enzyme in metabolic activation of aflatoxin $\mathrm{G} 1$ in human bronchial epithelial cells. Arch Toxicol 87, 1697-1707, doi:10.1007/s00204-013-1108-3 (2013).

29. Wang, J. et al. Biochanin A Protects Against Lipopolysaccharide-Induced Damage of Dopaminergic Neurons Both In Vivo and In Vitro via Inhibition of Microglial Activation. Neurotox Res 30, 486-498, doi:10.1007/s12640-016-9648-y (2016).

30. Ki, S. H. et al. Artificial vesicles as an animal cell model for the study of biological application of nonthermal plasma. J Phys D Appl Phys 49, doi:Artn 085401 10.1088/0022-3727/49/8/085401 (2016).

31. Hadi, L. M., Yaghini, E., Stamati, K., Loizidou, M. \& MacRobert, A. J. Therapeutic enhancement of a cytotoxic agent using photochemical internalisation in 3D compressed collagen constructs of ovarian cancer. Acta Biomater 81, 80-92, doi:10.1016/j.actbio.2018.09.041 (2018).

32. Al-Katib, A. M. et al. Isolation and characterization of a CD34(+) sub-clone in B-cell lymphoma. Oncotarget 11, 148-160, doi:10.18632/oncotarget.27415 (2020).

33. Lelliott, P. M. et al. Rapid Quantification of NETs In Vitro and in Whole Blood Samples by Imaging Flow Cytometry. Cytometry A 95, 565-578, doi:10.1002/cyto.a.23767 (2019). 
34. Tay, J. et al. Imaging flow cytometry reveals that granulocyte colony-stimulating factor treatment causes loss of erythroblastic islands in the mouse bone marrow. Exp Hemato/ 82, 33-42, doi:10.1016/j.exphem.2020.02.003 (2020).

35. Purschke, M., Rubio, N., Held, K. D. \& Redmond, R. W. Phototoxicity of Hoechst 33342 in time-lapse fluorescence microscopy. Photochem Photobio/ Sci 9, 1634-1639, doi:10.1039/c0pp00234h (2010).

36. Canitrot, Y., Lahmy, S., Buquen, J. J., Canitrot, D. \& Lautier, D. Functional study of multidrug resistance with fluorescent dyes. Limits of the assay for low levels of resistance and application in clinical samples. Cancer Lett 106, 59-68, doi:Doi 10.1016/0304-3835(96)04301-7 (1996).

37. Siemann, D. W. \& Keng, P. C. Cell cycle specific toxicity of the Hoechst 33342 stain in untreated or irradiated murine tumor cells. Cancer Res 46, 3556-3559 (1986).

38. Purschke, M., Rubio, N., Held, K. D. \& Redmond, R. W. Phototoxicity of Hoechst 33342 in time-lapse fluorescence microscopy. Photoch Photobio Sci 9, 1634-1639, doi:10.1039/c0pp00234h (2010).

39. Hammond, C. L., Madejczyk, M. S. \& Ballatori, N. Activation of plasma membrane reduced glutathione transport in death receptor apoptosis of HepG2 cells. Toxicol Appl Pharmacol 195, 12-22, doi:10.1016/j.taap.2003.10.008 (2004).

40. Cao, M. R. et al. Harmine induces apoptosis in HepG2 cells via mitochondrial signaling pathway. Hepatobiliary Pancreat Dis Int 10, 599-604, doi:10.1016/s1499-3872(11)60102-1 (2011).

41. Beaton-Green, L. A. \& Wilkins, R. C. Quantitation of Chromosome Damage by Imaging Flow Cytometry. Methods Mol Biol 1389, 97-110, doi:10.1007/978-1-4939-3302-0_6 (2016).

42. Bogush, T. A. et al. A new approach to epithelial-mesenchymal transition diagnostics in epithelial tumors: double immunofluorescent staining and flow cytometry. Biotechniques, doi:10.2144/btn2020-0024 (2020).

43. Zhang, L. J., Li, Z. Q., Yang, Y. P., Li, X. W. \& Ji, J. F. Tunicamycin suppresses cisplatin-induced HepG2 cell apoptosis via enhancing p53 protein nuclear export. Mol Cell Biochem 327, 171-182, doi:10.1007/s11010-009-0055-z (2009).

44. Yang, S. K. et al. Mitochondria targeted peptide SS-31 prevent on cisplatin-induced acute kidney injury via regulating mitochondrial ROS-NLRP3 pathway. Biomedicine \& pharmacotherapy $=$ Biomedecine \& pharmacotherapie 130, 110521, doi:10.1016/j.biopha.2020.110521 (2020).

45. Garcia, C. P. et al. Topoisomerase I inhibitor, camptothecin, induces apoptogenic signaling in human embryonic stem cells. Stem Cell Res 12, 400-414, doi:10.1016/j.scr.2013.12.002 (2014).

46. Rath, G. et al. De novo ceramide synthesis is responsible for the anti-tumor properties of camptothecin and doxorubicin in follicular thyroid carcinoma. Int J Biochem Cell B 41, 1165-1172, doi:10.1016/j.biocel.2008.10.021 (2009).

47. Ding, Y. M., Wang, B., Chen, X. Y., Zhou, Y. \& Ge, J. H. Staurosporine suppresses survival of HepG2 cancer cells through Omi/HtrA2-mediated inhibition of PI3K/Akt signaling pathway. Tumor Bio/39, doi:Artn 694317 10.1177/1010428317694317 (2017).

48. Deshmukh, M. \& Johnson, E. M. Staurosporine-induced neuronal death: multiple mechanisms and methodological implications. Cell Death and Differentiation 7, 250-261, doi:DOI 
10.1038/sj.cdd.4400641 (2000).

49. Petkovic, J. et al. DNA damage and alterations in expression of DNA damage responsive genes induced by TiO2 nanoparticles in human hepatoma HepG2 cells. Nanotoxicology 5, 341-353, doi:10.3109/17435390.2010.507316 (2011).

50. Ji, Y. B. \& Gao, S. Y. Arylamine N-acetyltransferases: a new inhibitor of apoptosis in HepG2 cells. J Zhejiang Univ-Sc B 9, 701-706, doi:10.1631/jzus.B0820090 (2008).

51. Gorman, A. M., Hirt, U. A., Orrenius, S. \& Ceccatelli, S. Dexamethasone pre-treatment interferes with apoptotic death in glioma cells. Neuroscience $96,417-425$, doi:Doi 10.1016/S0306-4522(99)00565-5 (2000).

52. Park, M. S., De Leon, M. \& Devarajan, P. Cisplatin induces apoptosis in LLC-PK1 cells via activation of mitochondrial pathways. J Am Soc Nephro/ 13, 858-865 (2002).

53. Schweyer, S. et al. Cisplatin-induced apoptosis in human malignant testicular germ cell lines depends on MEK/ERK activation. Brit J Cancer 91, 589-598, doi:10.1038/sj.bjc.6601919 (2004).

54. Rathinam, R., Ghosh, S., Neumann, W. L. \& Jamesdaniel, S. Cisplatin-induced apoptosis in auditory, renal, and neuronal cells is associated with nitration and downregulation of LMO4. Cell Death Discov 1, doi:Artn 15052 10.1038/Cddiscovery.2015.52 (2015).

55. Yasuda, M., Kishimoto, S., Amano, M. \& Fukushima, S. The Involvement of Pregnane X Receptorregulated Pathways in the Antitumor Activity of Cisplatin. Anticancer Res 39, 3601-3608, doi:10.21873/anticanres.13507 (2019).

56. Chaudhuri, A. R. \& Nussenzweig, A. The multifaceted roles of PARP1 in DNA repair and chromatin remodelling. Nat Rev Mol Cell Bio 18, 610-621, doi:10.1038/nrm.2017.53 (2017).

57. Chaitanya, G. V., Steven, A. J. \& Babu, P. P. PARP-1 cleavage fragments: signatures of cell-death proteases in neurodegeneration. Cell Commun Signa/ 8, doi:Artn 31 10.1186/1478-811x-8-31 (2010).

58. Kaufmann, S. H., Desnoyers, S., Ottaviano, Y., Davidson, N. E. \& Poirier, G. G. Specific Proteolytic Cleavage of Poly(Adp-Ribose) Polymerase - an Early Marker of Chemotherapy-Induced Apoptosis. Cancer Res 53, 3976-3985 (1993).

59. Ju, S. M. et al. Phosphorylation of elF2 alpha suppresses cisplatin-induced p53 activation and apoptosis by attenuating oxidative stress via ATF4-mediated HO-1 expression in human renal proximal tubular cells. Int J Mol Med 40, 1957-1964, doi:10.3892/ijmm.2017.3181 (2017).

60. Hayakawa, J., Depatie, C., Ohmichi, M. \& Mercola, D. The activation of c-Jun NH2-terminal kinase (JNK) by DNA-damaging agents serves to promote drug resistance via activating transcription factor 2 (ATF2)-dependent enhanced DNA repair. Journal of Biological Chemistry 278, 20582-20592, doi:10.1074/jbc.M210992200 (2003).

61. Brozovic, A. et al. Long-term activation of SAPK/JNK, p38 kinase and Fas-L expression by cisplatin is attenuated in human carcinoma cells that acquired drug resistance. Int $J$ Cancer 112, 974-985, doi:10.1002/ijc.20522 (2004).

62. Lee, D., Lee, S. R., Kang, K. S. \& Kim, K. H. Benzyl salicylate from the stems and stem barks of Cornus walteri as a nephroprotective agent against cisplatin-induced apoptotic cell death in LLC-PK1 cells. 
RSC Advances 10, 5777-5784, doi:10.1039/c9ra07009e (2020).

63. Lau, A. H. Apoptosis induced by cisplatin nephrotoxic injury. Kidney International 56, 1295-1298, doi:DOI 10.1046/j.1523-1755.1999.00687.x (1999).

64. Ryan, M. J. et al. HK-2: an immortalized proximal tubule epithelial cell line from normal adult human kidney. Kidney Int 45, 48-57, doi:10.1038/ki.1994.6 (1994).

65. Hauschke, M. et al. Neutrophil gelatinase-associated lipocalin production negatively correlates with HK-2 cell impairment: Evaluation of NGAL as a marker of toxicity in HK-2 cells. Toxicol In Vitro 39, 5257, doi:10.1016/j.tiv.2016.11.012 (2017).

66. Handl, J. et al. Transient increase in cellular dehydrogenase activity after cadmium treatment precedes enhanced production of reactive oxygen species in human proximal tubular kidney cells. Physiol Res 68, 481-490, doi:10.33549/physiolres.934121 (2019).

67. Capek, J., Hauschke, M., Bruckova, L. \& Rousar, T. Comparison of glutathione levels measured using optimized monochlorobimane assay with those from ortho-phthalaldehyde assay in intact cells. $J$ Pharmacol Tox Met 88, 40-45, doi:10.1016/j.vascn.2017.06.001 (2017).

\section{Figures}



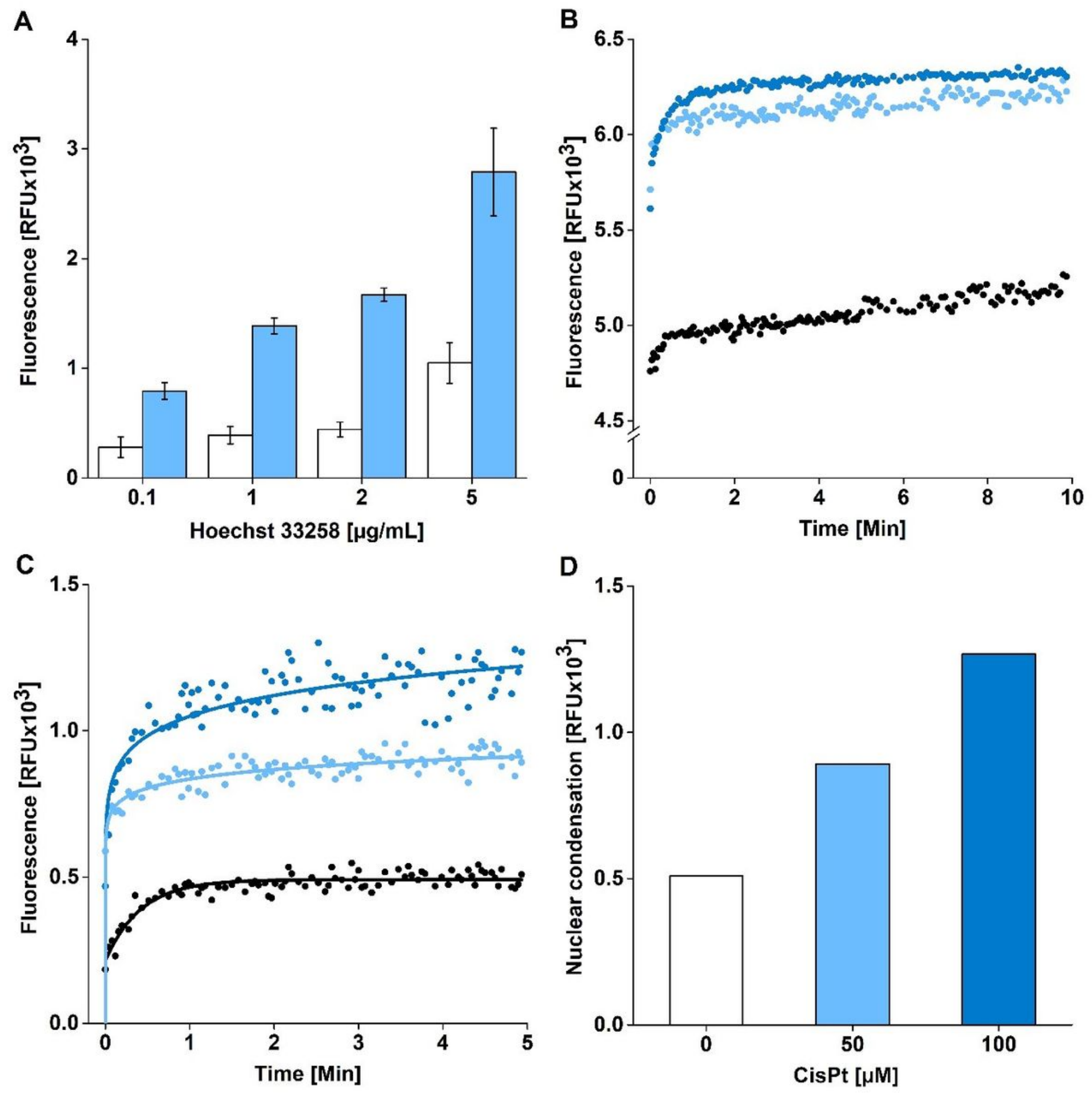

Figure 1

Optimization of the spectrofluorometric assay for detection of nuclear condensation and fragmentation in HepG2 cells. (A) Optimization of H33258 concentration $(0.1 ; 1 ; 2 ; 5 \mu \mathrm{g} / \mathrm{mL}$ ) - untreated cells (white columns), $100 \mu \mathrm{M}$ cisplatin treated cells (blue columns). Mean \pm SEM $(n=3)$. (B) Change of intensity of fluorescence over time. HepG2 cells were treated with CisPt for $24 \mathrm{~h}$. Then, the cells were incubated with $\mathrm{H} 33258(2 \mu \mathrm{g} / \mathrm{mL})$ and fluorescence $(E X / E M=352 / 461 \mathrm{~nm})$ was recorded for $10 \mathrm{~min}$. Untreated cells (black), $50 \mu \mathrm{M}$ CisPt (light blue), $100 \mu \mathrm{M}$ CisPt (dark blue). (C, D) Detection of nuclear condensation and 
fragmentation in cells. HepG2 cells were treated with cisplatin for $24 \mathrm{~h}$. Then, the cells were incubated with H33258 $(2 \mu \mathrm{g} / \mathrm{mL})$ and fluorescence $(E X / E M=352 / 461 \mathrm{~nm})$ was recorded for $5 \mathrm{~min}$. Finally, the background fluorescence was subtracted and fluorescence intensity corresponding to the extent of nuclear condensation and fragmentation was showed in untreated (white), $50 \mu \mathrm{M}$ (light blue) and $100 \mu \mathrm{M}$ CisPt (dark blue) treated cells $(=\mathrm{C})$. The fluorescence intensity attributed to the extent of nuclear condensation and fragmentation was compared among untreated cells (white), $50 \mu \mathrm{M}$ CisPt (light blue), $100 \mu \mathrm{M}$ CisPt (dark blue) treated cells (= D).
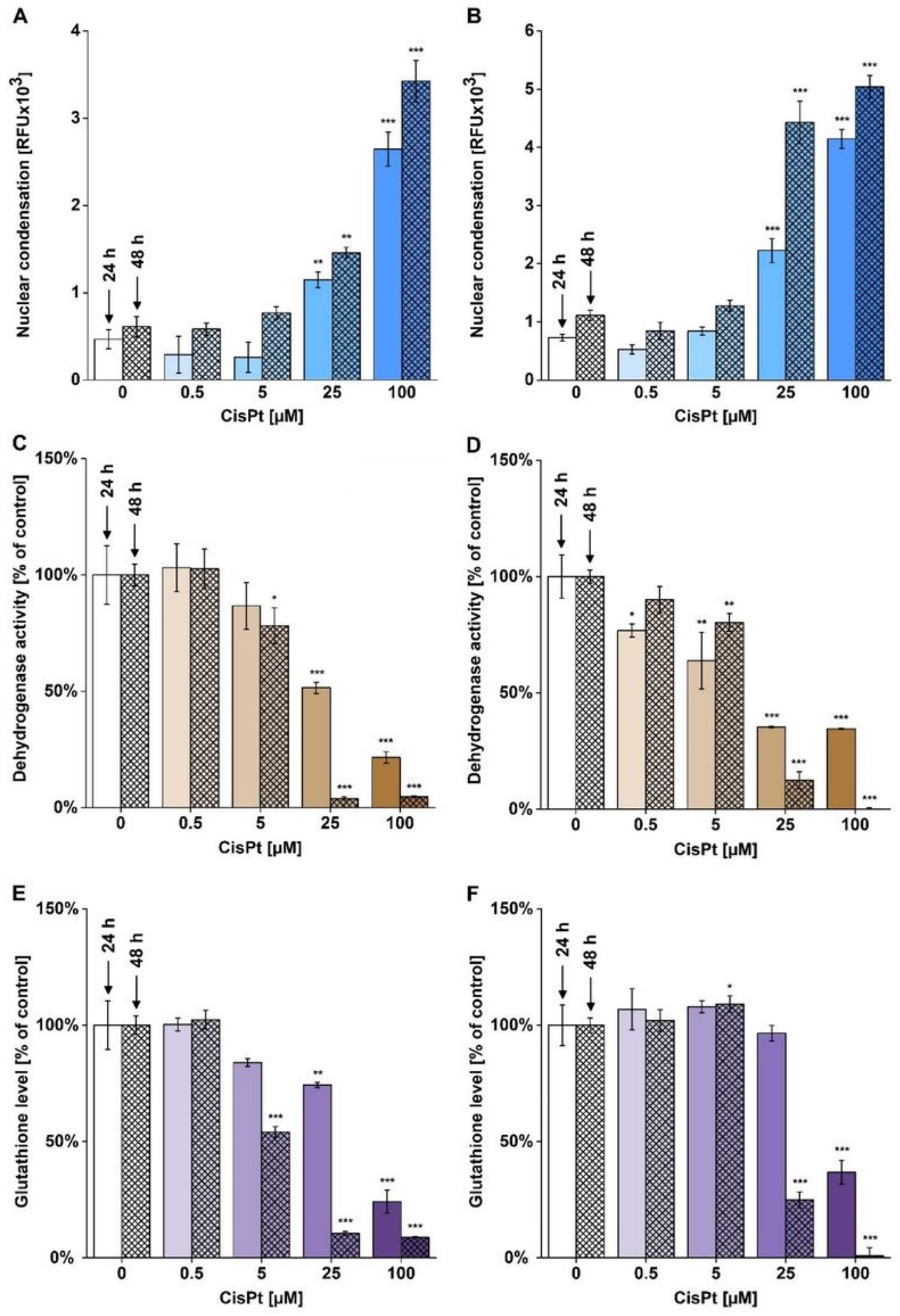
Figure 2

Characterizing cisplatin-induced toxicity in HepG2 and HK-2 cells. HepG2 (A, C, E) and HK-2 (B, D, F) cells were incubated with cisplatin (CisPt; $0 ; 0.5 ; 5 ; 25$ and $100 \mu \mathrm{M}$ ) for 24 and $48 \mathrm{~h}$. After treatment, nuclear condensation and fragmentation using the $\mathrm{H} 33258$ spectrofluorometric assay (A, B), dehydrogenase activity using the WST-1 test $(C, D)$ and glutathione levels using monochlorobimane assay $(E, F)$ were measured. The data are presented as mean $\pm \operatorname{SEM}(A, B)$ and mean $\pm \operatorname{SD}(C-F) .\left({ }^{*}, p<0.05 ; * \star, p<0.01 ; * \star \star\right.$, $p<0.001$, vs. untreated cells at appropriate time interval).
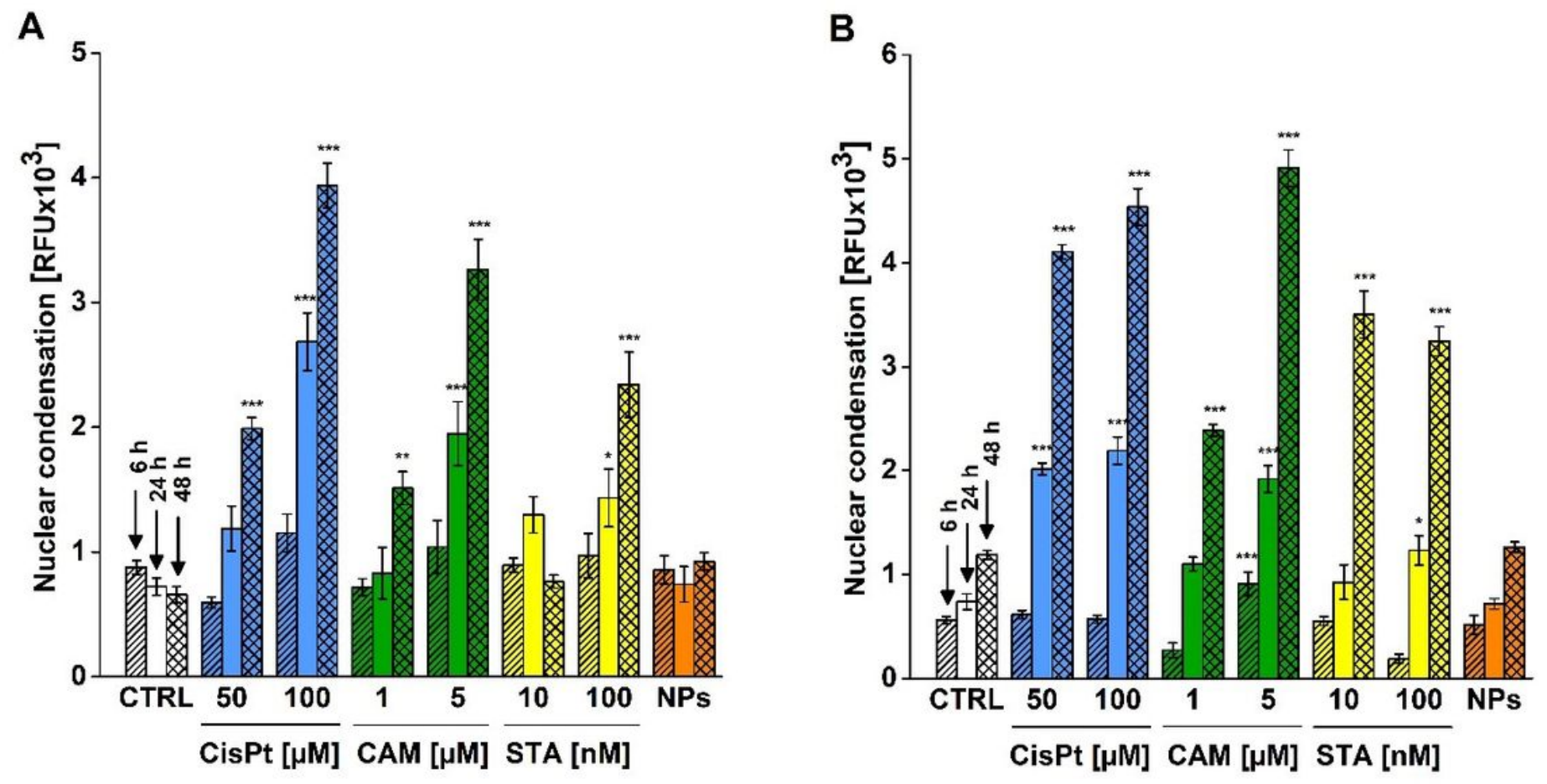

Figure 3

Detection of nuclear condensation and fragmentation using the H33258 spectrofluorometric assay. HepG2 (A) and HK-2 (B) cells were treated with cisplatin (CisPt, 50; $100 \mu \mathrm{M}$, blue columns), camptothecin (CAM, 1; $5 \mu \mathrm{M}$, green columns), staurosporine (STA, 10; $100 \mathrm{nM}$, yellow columns) for 6,24 and $48 \mathrm{~h}$. Control (CTRL) represents untreated cells. The cells treated with TiO2 P25 nanoparticles (NPs, $10 \mu \mathrm{g} / \mathrm{mL}$, orange columns) were used as a negative control. After treatment, the cells were incubated with $\mathrm{H} 33258$ $(2 \mu \mathrm{g} / \mathrm{mL})$ for $5 \mathrm{~min}$ and intensity fluorescence (EX/EM $=352 / 461 \mathrm{~nm})$ was measured. Then, the background fluorescence was subtracted and the extent of nuclear condensation was expressed in RFU. Data are presented as mean \pm SEM $(n=8-20) .\left({ }^{*}, p<0.05 ; * \star, p<0.01 ; * \star \star, p<0.001 ;\right.$ vs. untreated cells at appropriate time interval). 

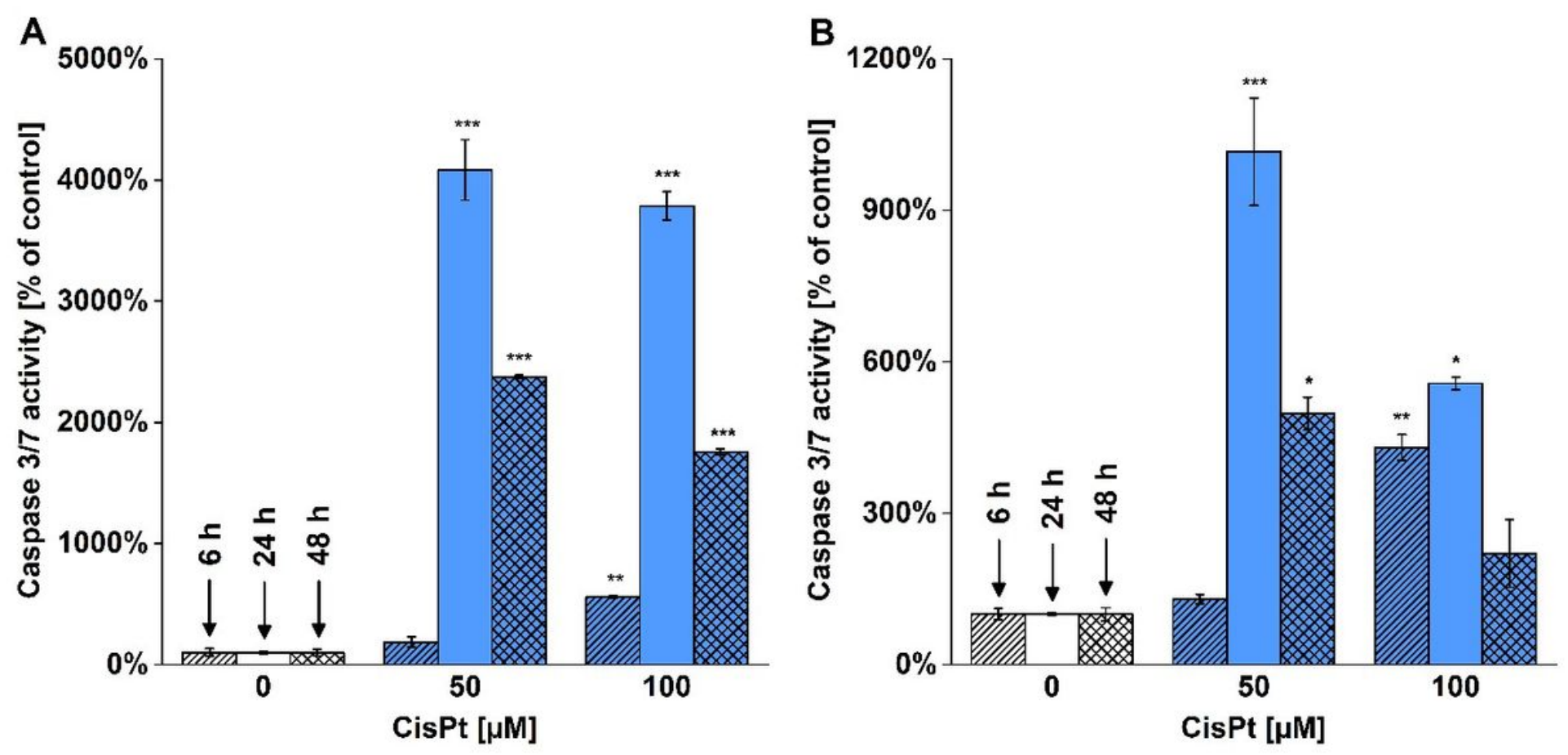

Figure 4

Caspase 3/7 activity in CisPt treated cells. HepG2 (A) and HK-2 (B) cells were treated with CisPt (50 and $100 \mu \mathrm{M})$ for 6,24 and $48 \mathrm{~h}$. After incubation, the activity of caspases $3 / 7$ was measured (EX/EM = $485 / 535 \mathrm{~nm})$. Data are presented as mean $\pm \operatorname{SEM}(n=2) .\left({ }^{*}, p<0.05 ;{ }^{* *}, p<0.01 ; * \star *, p<0.001\right.$; vs. untreated cells at appropriate time interval). 
HepG2

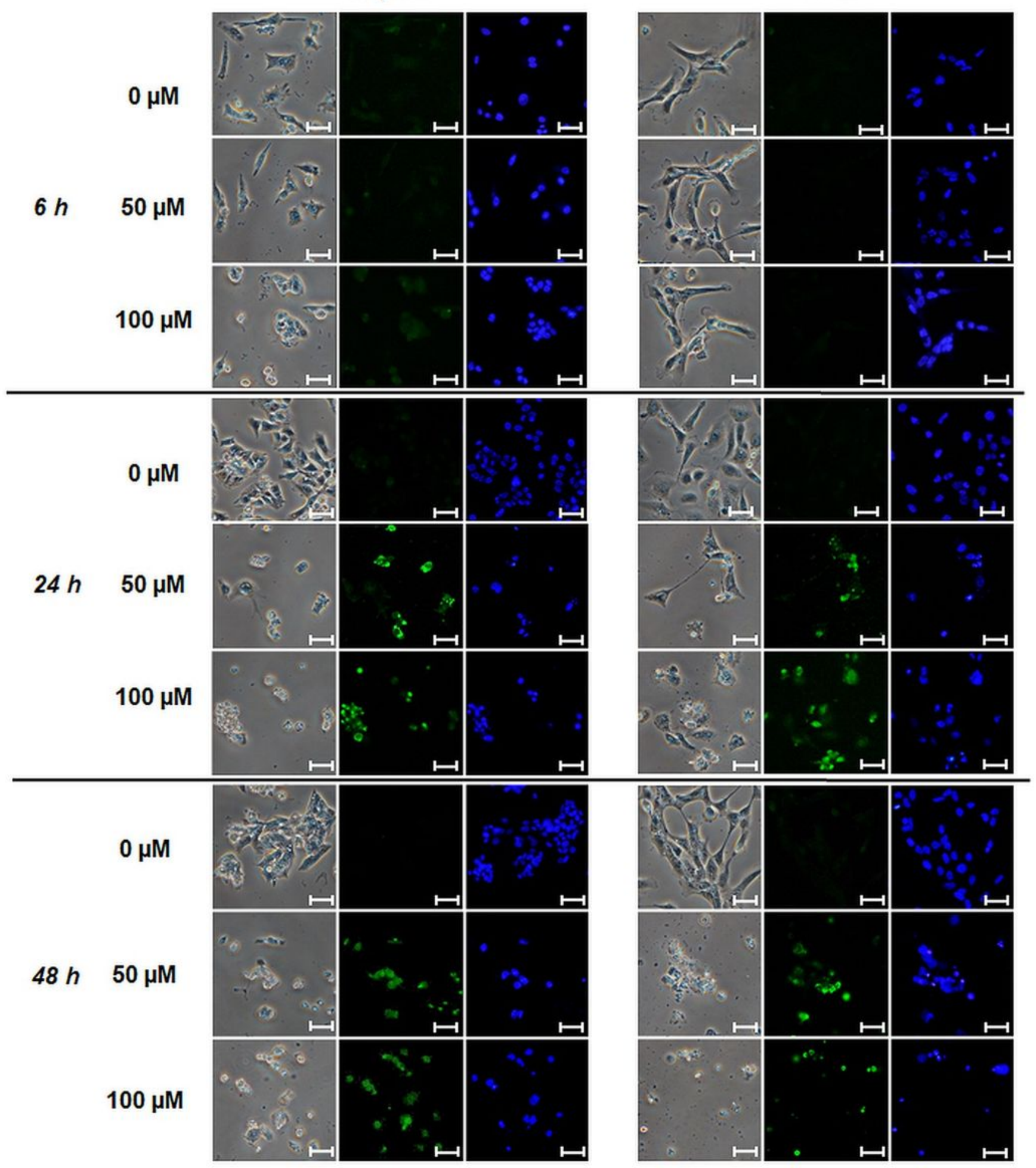

\section{Figure 5}

TUNEL assay in CisPt treated cells. HepG2 and HK-2 cells were treated with CisPt (50 and $100 \mu \mathrm{M})$ for 6 , 24 and $48 \mathrm{~h}$. Then, the cells and nuclei were visualized using phase contrast (left, magnification 400x), TUNEL (FITC 480/30 nm; middle) and Hoechst 33258 stainings (DAPI 375/28 nm; right). Scales correspond to $25 \mu \mathrm{m}$. 
A

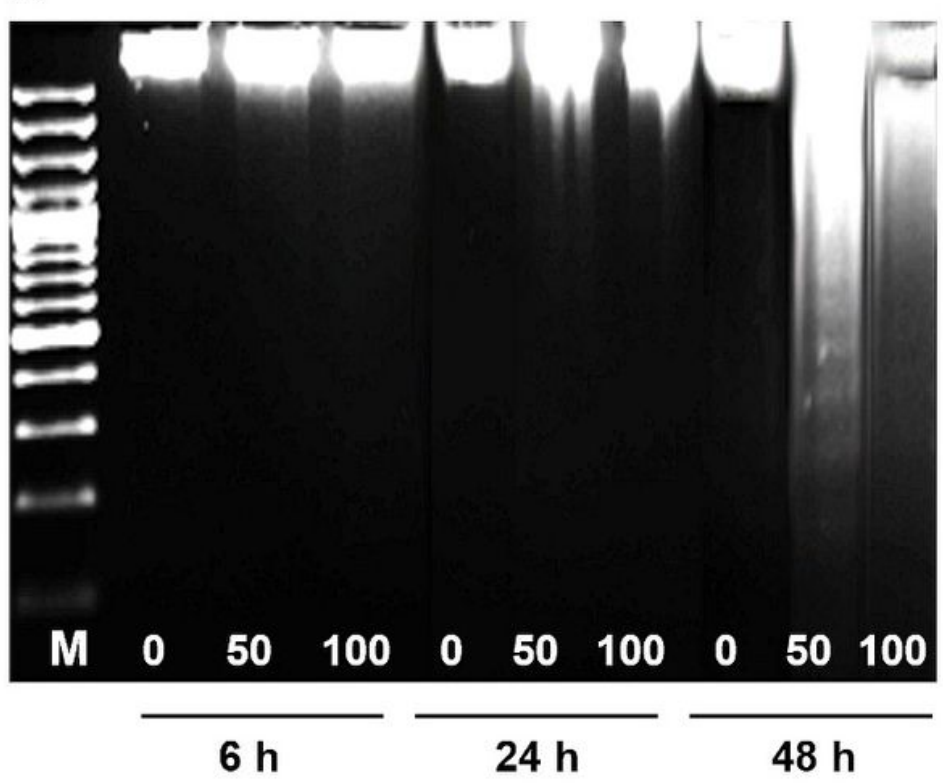

B

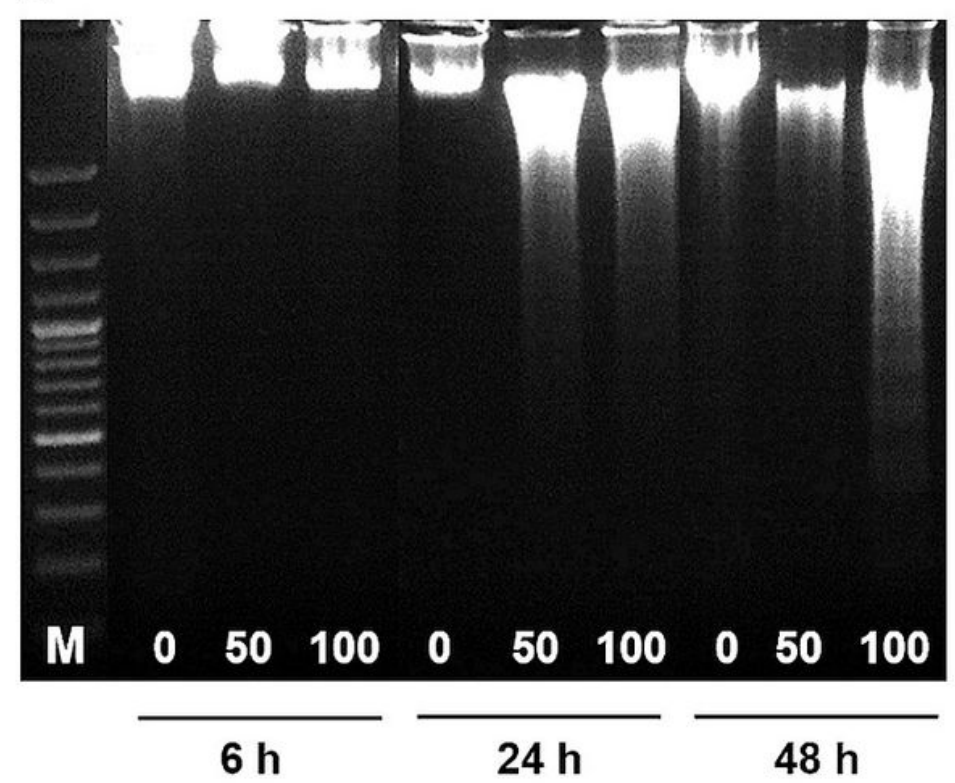

Figure 6

DNA ladder assay in CisPt treated cells. HepG2 (A) and HK-2 (B) cells were treated with CisPt (50 and 100 $\mu \mathrm{M})$ for 6,24 and $48 \mathrm{~h}$. After DNA isolation, DNA ladder assay was performed. (0, untreated cells; 50, 50 $\mu \mathrm{M}$ CisPt; 100, $100 \mu \mathrm{M}$ CisPt; M, 100 bp marker). 